\title{
PERUBAHAN SISTEM KEBIJAKAN PENDIDIKAN TINGGI DALAM DIMENSI PENDIDIKAN HUKUM
}

Alfalachu indiantoro, Wafda Vivid

Fakultas Hukum, Universitas Muhammadiyah Ponorogo

Jl. Budi Utomo No.10, Ronowijayan, Siman, Kabupaten Ponorogo, Jawa Timur 63471

Telp/Fax: (0352) 481124, e-mail: intoro60@ gmail.com

\begin{abstract}
Abstrak
Pembaharuan sistem kebijakan Pendidikan merupakan usaha sadar dan terencana untuk mewujudkan suasana belajar dan proses pembelajaran agar peserta didik dapat secara aktif mengembangkan potensi dirinya untuk memiliki kekuatan spiritual keagamaan, pengendalian diri, kecerdasan, serta ketrampilan yang diperlukan dirinya, masyarakat, bangsa, dan negara. Tujuan pendidikan untuk mencerdaskan kehidupan Seluruh rakyat Indonesia tanpa terkecuali, Kurikulum pendidikan tinggi saat ini berbasis kompetensi yang mengacu pada kualifikasi akademik. Alasan dilakukannya pembaharuan sistem kebijakan pendidikan tinggi adalah karena kualitas lulusan pendidikan tinggi yang belum mampu menjawab kebutuhan dan daya saing global. Serta ketimpangan antara profil lulusan pendidikan tinggi dengan standar kualifikasi tenaga kerja yang dibutuhkan pasar kerja.
\end{abstract}

Kata kunci : pembaharuan, kebijakan, pendidikan

\section{A. Pendahuluan}

Pendidikan merupakan optimalisasi potensi ${ }^{1}$ dimana dilakukan dengan usaha sadar dan terencana untuk mewujudkan suasana belajar dan proses pembelajaran agar peserta didik dapat secara aktif mengembangkan potensi dirinya untuk memiliki kekuatan spiritual keagamaan, pengendalian diri, kecerdasan, serta ketrampilan yang diperlukan dirinya, masyarakat, bangsa, dan negara. ${ }^{2}$ menurut Presiden Soekarno bahwa : "Bangsa yang

\footnotetext{
${ }^{1}$ Suyadi , (2012), Integrasi Pendidikan Islam Dan Neurosains Dan Implikasinya Bagi Pendidikan Dasar (Pgmi), Al-Bidāyah, Vol 4 No. 1, Juni.

${ }^{2}$ Ateng Syafrudin, (2008), Catatan Kecil Tentang Pemerintahan, Pendidikan dan Hukum, dalam Sri Rahayu Oktoberina dan Niken Savitri (Ed.), Butir-
}

besar ialah bangsa yang mampu mewujudkan mimpi yang besar". Perwujudan itu memerlukan sejumlah syarat. Salah satu jembatan yang perlu mendapat perhatian serius adalah pendidikan. $^{3}$

Tujuan pendidikan di indonesia ialah untuk mencerdaskan kehidupan Seluruh rakyat Indonesia tanpa terkecuali: ${ }^{4}$ Melindungi segenap bangsa Indonesia dan

butir Pemikiran Dalam Hukum, Memperingati 70 Tahun Prof. Dr. B. Arief Sidharta, S.H., Cetakan Pertama, Refika Aditama, Bandung, hlm.71

${ }^{3}$ Forum Mangunwijaya, (2007), Kurikulum yang Mencerdaskan, Visi 2030 dan Pendidikan Alternatif, Cetakan Pertama, Kompas Media Nusantara, Jakarta, hlm. 97 dan 98.

${ }^{4}$ Ibid., hlm. 4. 
tumpah darah Indonesia, memajukan kesejahteraan umum dan kemakmuran rakyat, mencerdasnya kehidupan bangsa, menjunjung tinggi martabat Indonesia dalam percaturan global baik politik, ekonomi, serta Iptek; dan Bukan hanya terlaksana tidaknya demokrasi sebagai suatu sarana untuk men-capai tujuan.

Sumber daya manusia yang berkualitas akan membuat suatu negara menjadi disegani oleh bangsa lainnya, melalui pendidikanlah semua dapat diwujudkan. ${ }^{5}$ Pendidikan tinggi, saat ini menjadi syarat dalam mencari sebuah pekerjaan atau menjalankan suatu profesi.

Mengenai pendidikan tinggi diatur di dalam Undang-Undang Nomor 12 Tahun 2012 tentang Pendidikan Tinggi; Peraturan Menteri Pendidikan dan Kebudayaan Republik Indonesia Nomor 49 Tahun 2014 tentang Standar Nasional Pendidikan Tinggi, Peraturan Menteri Riset, Teknologi, dan Pendidikan Tinggi Republik Indonesia Nomor 44 Tahun 2015 tentang Standar Nasional Pendidikan Tinggi; Peraturan Pemerintah Nomor 66 Tahun 2010 tentang Perubahan Atas Peraturan Pemerintah Nomor 17 Tahun 2010 tentang Pengelolaan dan

\footnotetext{
${ }^{5}$ Abdul Ghofur Anshori dan Shobirin Malian (Ed), (2008), Membangun Hukum Indonesia, Kumpulan Pidato Guru Besar Ilmu Hukum dan Filsafat, Cetakan Pertama, Kreasi Total Media, Yogyakarta, hlm. $59-60$.
}

Penyelenggaraan Pendidikan, dan Peraturan Pemerintah Nomor 4 Tahun 2014 tentang Penyelenggaraan Pendidikan Tinggi dan Pengelolaan Perguruan Tinggi.

Dalam rangka mewujudkan tujuan negara kesejahteraan, pemerintah turut campur tangan dalam menetapkan kebijakan antara lain dalam menetapkan kurikulum pendidikan tinggi. Kurikulum merupakan pencerminan dari semua citacita dan pikiran dalam pendidikan. ${ }^{6}$ Kurikulum pendidikan tinggi di Indonesia sering mengalami perubahan, bahkan setiap tahunnya, dengan cara peng-ajaran yang berbeda-beda.

Meskipun sering terjadi perubahan kebijakan pendidikan tinggi di Indonesia, output dari pendidikan tinggi di Indonesia belum dapat mencetak lulusan pendidikan tinggi siap dalam menghadapi perubahan yang sangat cepat di era globalisasi, sehingga kebijakan pendidikan tinggi di Indonesia perlu dilakukan reformasi agar dapat memenuhi tuntutan perubahan, terutama akibat dari adanya pengaruh globalisasi dewasa ini

\footnotetext{
${ }^{6}$ Esmi Warassih, (2011), Pranata Hukum Sebuah Telaah Sosiologis, Cetakan Kedua, Badan Penerbit Universitas Diponegoro, Semarang, hlm. 179.
} 


\section{B. Metode Penelitian}

Metode Penelitian hukum ini menggunakan pendekatan konseptual (conceptual approach) dengan melakukan analisis terkait perubahan kebijakan sistem pendidikan tinggi dalam dimensi pendidikan hukum berdasarkan doktrin dan pandangan para ahli serta pandangan konseptual dan teoritis, hal ini bertujuan untuk memecahkan isu hukum yang diajukan tidak hanya dengan pendekatan perundang-undangan semata yang bersifat terbatas. $^{7}$

\section{Pembahasan}

Pengaturan pelaksanaan pendidikan tinggi di Indonesia;

Sejarah peradaban dunia menunjukkan peranan sistem pendidikan, ter-utama sejak era industrialisasi, dalam proses peradaban dunia menjadi modern, dan lebih dari itu, keberhasilan gerakan negara kebangsaan baik Jerman, Amerika Serikat, maupun negara kebangsaan lainnya juga berkat sistem pen-didikan (persekolahan) nasional masing-masing negara tersebut. ${ }^{8}$ empat abad Sebelum Masehi, plato sudah menempatkan

\footnotetext{
7 Peter Mahmud Marzuki, (2005), Penelitian hukum, Kencana Prenada Group: Jakarta, hlm.137140.

${ }^{8}$ Forum Mangunwijaya, Op.Cit., hlm. 9.
}

pendidikan sebagai landasan dan pengawal tegaknya suatu masyarakat. ${ }^{9}$

Bangsa Indonesia terus-menerus melakukan perbaikan dalam peningkat-an kualitas pendidikannya. Indonesia merupakan salah satu dari banyak negara yang memasukkan ketentuan tentang pendidikan dalam Undang-Undang Dasar. $^{10}$

Pasal 1 angka 1 Undang-Undang Nomor 12 Tahun 2012 menyebutkan bahwa : Pendidikan adalah usaha sadar dan terencana untuk mewujudkan suasana belajar dan proses pembelajaran agar peserta didik secara aktif mengembangkan potensi dirinya untuk memiliki kekuatan spiritual keagamaan, pengendalian diri, kepribadian, kecerdasan, akhlak mulia, serta ketrampilan yang diperlukan dirinya, masyarakat, bangsa, dan negara.

Pendidikan tinggi yang merupakan bagian dari sistem pendidikan nasional merupakan peran strategis dalam mencerdaskan kehidupan bangsa dan memajukan ilmu pengetahuan dan teknologi. Pendidikan tinggi diharapkan dapat menjadi pencetak sumber daya manusia yang profesional, berdaya guna, dan bersaing dengan sumber daya manusia dari luar negeri.

\footnotetext{
${ }^{9}$ Ibid., hlm. 10 dan 11. ${ }^{10}$ Ibid.
} 
Saat ini, dunia sudah memasuki era globalisasi. Kehidupan antar bangsa sekarang yang tanpa batas, dan persaingan bebas dalam bidang ekonomi, politik, dan ilmu pengetahuan dan teknologi. Ini berarti seluruh rakyatnya harus menjadi warga negara dari bangsa yang modern, yang maknanya adalah warga negara yang rasional, demokratis, dan berorientasi ilmu pengetahuan dan teknologi dalam mengatasi masalah kehidupan sosial, ekonomi, dan politiknya. $^{11}$

Pembaharuan sistem pendidikan tinggi sangatlah penting dilakukan, mengingat beragam tantangan luar biasa baik skala lokal, nasional maupun internasional. Maka dari itu penyelenggaraan pendidikan tinggi harus dirubah secara total mengikuti perkembangan yang ada, di antaranya : (a) Perubahan kebijakan pendidikan tinggi yang mengikuti arus globalisasi; (b) Penyediaan pendidikan tinggi yang fleksibel, berkualitas, berorientasi pada mahasiswa, mengikuti pangsa pasar, mengikuti perkembangan ilmu pengetahuan dan teknologi, mencetak lulusan yang berdaya saing, melakukan riset dan menghasilkan inovasi; (c) Perubahan kurikulum pendidikan tinggi; (d) Penyediaan tenaga pengajar, yakni dosen,

${ }^{11}$ Ibid. guru besar, dan tenaga pendidik yang berkualitas dan profesional.

Untuk mewujudkan nya, maka dalam pendidikan, baik perguruan tinggi negeri maupun swasta mengembangkan kurikulum berdasarkan ke-rangka kualifikasi nasional Indonesia (KKNI). kurikulum pendidikan tinggi di Indonesia berbasis kompetensi (mengacu pada pencapaian kompetensi), yakni akumulasi ke-mampuan seseorang dalam m-laksanakan suatu deskripsi kerja secara terukur melalui asesmen yang terstruktur. ${ }^{12}$ Dengan kata lain, kurikulum pendidikan tinggi saat ini berbasis kompetensi yang mengacu pada kualifikasi akademik.

Dengan adanya KKNI, bertujuan cara pandang melihat kompetensi seseorang, tidak lagi semata ijazah tapi dengan melihat kepada kerangka kualifikasi yang disepakati secara nasional sebagai dasar pengakuan terhadap hasil pendidikan seseorang secara luas (formal, non-formal, atau informal) yang akuntanbel dan transparan. ${ }^{13}$

Kurikulum perguruan tinggi memang harusnya dilakukan perubahan, saat ini KKNI menjadi acuan pokok dalam

\footnotetext{
${ }^{12}$ Fitri, (2017), Kurikulum Nasional Berbasis Kompetensi Mengacu Pada KKNI, http://www.kopertis12.or.id/2013/04/28/kurikulumnasional-berbasis-kompetensi-mengacu-padakkni.html , [Akses 9 Agustus 2017] ${ }^{13}$ Ibid.
} 
penetapan kompetensi lulusan pendidikan akademik, pendidikan volasi dan pendidikan profesi.

1. Pembaharuan kebijakan pendidikan tinggi di Indonesia.

Kebijakan pendidikan tinggi yang selalu berganti dengan tujuan untuk meningkatkan mutu pendidikan, serta menghasilkan lulusan pendidikan tinggi yang dapat bersaing dan dapat menerima perubahan dan mampu beradaptasi dengan perubahan di era globalisasi, sepertinya belum dapat dilihat hasilnya secara memuaskan.

Ijazah pendidikan tinggi saat ini tidak menjadi jaminan untuk mendapat pekerjaan dengan mudah, karena daya saing di dunia kerja dengan para pekerja asing sebagai dampak adanya globalisasi, selain itu tidak dimilikinya skill dalam bekerja, sehingga mempersulit lulusan pendidikan tinggi untuk mendapatkan pekerjaan.

Selain hal tersebut, terdapat ketimpangan antara profil lulusan perguruan tinggi dengan kualifikasi tenaga kerja siap pakai yang dibutuhkan oleh perusahaan. Lulusan perguruan tinggi di Indonesia belum siap pakai, selama ini perguruan tinggi hanya mengajarkan mengenai ilmu logika atau teori-teori, tanpa adanya pengembangan kemampuan mahasiswa.

Selain hal tersebut, alasan diperlukannya pembaharuan kebijakan pendidikan tinggi ialah semakin banyaknya konvensi internasional yang diratifikasi oleh negara Indonesia, sehingga negara Indonesia harus menyesuaikan dan me-laksanakan isi konvensi tersebut, salah satunya adalah konvensi internasional tentang hak-hak ekonomi, sosial dan budaya.

Berdasarkan hasil studi Willis Towers Watson yang meneliti tentang praktik terbaik manajemen bakat dan program penghargaan karyawan pada tahun 2014 bahwa 8 dari 10 perusahaan di Indonesia kesulitan mendapatkan lulusan perguruan tinggi yang siap pakai. Untuk menanggapi kendala ini, tokoh pendidikan Indonesia, Prof. Dr. Arief Rachman mengatakan bahwa kita perlu memiliki konsep pendidikan tinggi yang modern untuk menciptakan lulusan yang kompeten dan memiliki skill yang mumpuni. $^{14}$

Adanya perubahan kurikulum dengan Kerangka Kualifikasi Nasional Indonesia sebagai acuan pokok, maka

\footnotetext{
${ }^{14}$ USAID, (2017), Reformasi Pendidikan Tinggi di Indonesia, http://www.prestasiiief.org/index.php/id/feature/108-reformasipendidikan-tinggi-di-indonesia, [Akses 9 Agustus 2017].
} 
diharapkan lulusan perguruan tinggi di Indonesia setara dan diakui kualifikasinya dengan sumber daya manusia dari luar negeri, sehingga sumber daya manusia Indonesia mampu bersaing dengan sumber daya manusia luar negeri.

2. Model pembaharuan sistem kebijakan pendidikan tinggi di Indonesia.

sebagaimana diketahui bahwa di indonesia pendidikan merupakan hak warga negara. Setiap warga negara wajib mengikuti pendidikan, tanpa dikenai biaya. Manusia Indonesia yang sesuai dengan tuntutan membangun bangsa sebagai diamanatkan Pembukaan Undang-Undang Dasar Negara Republik Indo-nesia Tahun 1945 adalah manusia yang bermoral, berdisiplin (pribadi, sosial, dan nasional) ${ }^{15}$ Untuk membangun sumber daya manusia yang sesuai dengan harapan bangsa, tidaklah semudah membalikkan telapak tangan. Segala macam ke-butuhan untuk memajukan pendidikan harus benar-benar sangat dipikirkan dan harus dipenuhi.

Manusia yang bermoral, berdisiplin, beretos kerja tinggi, dan mampu menguasai dan menerapkan ilmu pengetahuan dan teknologi serta demokratis dan bertanggung jawab tidak dapat dilahirkan dalam sistem pendidikan sekolah dengan peserta didik tanpa buku

${ }^{15}$ Ibid., hlm. 19-20. pelajaran, tanpa lapangan olah raga, tanpa laboratorium, tanpa perpustakaan, tanpa guru yang tidak berkomitmen kepada pendidikan anak karena rendahnya insentif dan kesejahteraan yang diterima, dan tanpa fasilitas esensial bagi sekolah sebagai pusat pembudayaan segala kemampuan, nilai, dan sikap, sehingga sekolah hanya menjadi tempat peserta didik untuk mendengar, mencatat, menghafal, dan latihan menjawab soal-soal ujian. Inilah kondisi lembaga pendidikan Indonesia pada umumnya dari Sekolah Dasar bahkan sampai tingkat universitas. Pada umumnya sekolah hanyalah tempat untuk bertemu guru di kelas.

Kondisi sekolah seperti ini yang pada umumnya terdapat di negara-negara berkembang oleh UNESCO dalam publikasinya pada tahun 1996 tidak dapat diharapkan untuk dapat menunjang pembangunan bangsa melainkan sebaliknya, akan melahirkan masalah-masalah baru, yaitu unprepared and unskilled educated young generation. ${ }^{16}$

Dalam rangka meningkatkan kemampuan peserta didik (mahasiswa), maka dapat dilakukan tidak hanya melalui pendidikan formal, akan tetapi perlu pula perguruan tinggi bekerjasama dengan instansi terkait agar mahasiswa dapat

${ }^{16}$ Ibid., hlm. 20-21. 
melakukan kuliah kerja, bekerjasama dengan perusahaan-perusahaan agar memperoleh pengalaman kerja, melakukan praktek profesi, maupun belajar secara mandiri, sehingga pada nantinya dapat dideskripsikan capaian pem-belajaran (learning outcomes) dari ukuran kemampuan mahasiswa dengan Kerangka Kualifikasi Nasional Indonesia sebagai acuan dengan melihat penguasaan ilmu pengetahuan, sikap, kemampuan kerja, serta tanggung jawab dari mahasiswa.

Komisi Internasional Unesco, memasuki abad ke-21 merekomendasikan 4 (empat) pilar belajar, yaitu : ${ }^{17}$

\section{a. Learning to know;}

Learning to know adalah suatu proses pembelajaran yang me-mungkinkan peserta didik menghayati dan akhirnya dapat merasakan dan dapat menerapkan cara memperoleh pengetahuan, suatu proses yang me-mungkinkan tertanamnya sikap ilmiah, yaitu sikap ingin tahu dan selanjut-nya menimbulkan rasa mampu untuk selalu mencari jawab atas masalah yang dihadapi secara ilmiah.

\section{b. Learning to do;}

Sasaran akhir dari diterapkannya pilar ini adalah lahirnya generasi muda yang dapat bekerja secara cerdas dengan memanfaatkan ilmu penge-tahuan dan

${ }^{17}$ Ibid., hlm. 22-27. teknologi. Pemahaman tentang pilar ini, pada berbagai jenjang pendidikan harus memungkinkan peserta didik dalam proses pembelajarannya sampai pada tingkatan penggunaan berbagai konsep, prinsip, atau hukum untuk memecahkan masalah yang konkret. Ini jelas memerlukan suatu lembaga pendidikan dengan tenaga guru berderajat profesional, sarana dan prasarana yang memadai dan suasana pembelajaran yang penuh tantangan.

c. Learning to live together; dan

Pendidikan tidak hanya membekali generasi muda untuk menguasai ilmu pengetahuan dan teknologi dan kemampuan bekerja serta memecahkan masalah, melainkan kemampuan untuk hidup bersama dengan orang lain yang berbeda dengan penuh toleransi, pengertian, dan tanpa prasangka. Tugas pendidikan untuk pada saat yang bersamaan, setiap peserta didik memperoleh pengetahuan dan memiliki kesadaran bahwa hakikat manusia adalah beragam, tetapi dalam keragaman tersebut terdapat persamaan. Pendidikan untuk mencapai tingkat kesadaran akan persamaan antar sesama manusia dan terdapat saling keter-gantungan satu sama lain, tidak dapat ditempuh dengan pendidikan dengan pendekatan tradisional, melainkan perlu menciptakan situasi 
kebersamaan dalam waktu yang relatif lama.

\section{d. Learning to be}

Tiga pilar, yaitu learning to know, learning to do, dan learning to live together ditujukan bagi lahirnya generasi muda yang mampu mencari informasi dan/atau menemukan ilmu pengetahuan, yang mampu melaksana-kan tugas dalam memecahkan masalah secara cerdas, dan mampu bekerja-sama, bertenggang rasa, dan toleran terhadap perbedaan. Bila ketiganya berhasil dengan memuaskan akan menimbulkan adanya rasa percaya diri pada masing-masing peserta didik, hasil akhirnya adalah manusia yang mampu mengenal dirinya, dalam bahasa Undang-Undang Nomor 2 Tahun 1989 adalah manusia yang ber-kepribadian mantap dan mandiri.

Manusia yang utuh yang memiliki kemantapan emosional dan intelektual, yang mengenal dirinya, yang dapat mengendalikan dirinya, yang konsisten dan yang memiliki rasa empati (tepo sliro), atau dalam kamus psikologi disebut memiliki emotional intelligence. Inilah kurang lebih makna learning to be, yaitu muara akhir dari tiga pilar belajar.

Dengan adanya kebijakan pendidikan tinggi yang baru, maka perguruan tinggi di Indonesia diharapkan melakukan suatu inovasi atau terobosan baru agar lulusannya memiliki kemampuan yang dibutuhkan oleh perusahaan baik di dalam maupun di luar negeri. Tidak hanya itu, semangat untuk berwiraswasta perlu diberikan, sehingga lulusan perguruan tinggi tidak hanya mampu sebagai tenaga kerja yang memiliki skill dan profesional, tetapi juga mampu men-ciptakan lapangan kerja dan dapat mengurangi tingkat pengangguran.

Agar dapat menetapkan kebijakan pendidikan tinggi yang baik, maka pemerintah dan perguruan tinggi dapat mengikutsertakan pihak swasta untuk menyusun kurikulum yang tepat bagi perguruan tinggi. Pihak swasta dapat memberikan masukan dan apa yang perlu dilakukan oleh para mahasiswa untuk mendapatkan pekerjaan yang baik, karena pihak swasta memiliki pengalaman di lapangan.

Tidak kalah penting dari adanya peningkatan kemampuan para lulusan pendidikan tinggi yang mengikuti perkembangan ilmu pengetahuan dan tekno-logi sebagai implikasi dai era globalisasi adalah karakter manusia Indonesia. Merupakan sebuah pekerjaan yang besar bagi bangsa Indonesia untuk mem-bentuk karakter manusia Indonesia menjadi yang beretos kerja tinggi, yang 
berdisiplin, yang bermoral, yang bertanggung jawab, yang menghormati tegak-nya hukum, dan yang mampu menguasai dan menerapkan ilmu pengetahuan dan teknologi, bersikap demokratis, dan berdaya saing global.

Untuk dapat menghasilkan manusia yang karakteristiknya digambarkan di atas, perlu dirancang dan diselenggarakan suatu sistem pendidikan nasional yang memungkinkan terjadinya proses pembelajaran yang bermakna proses pembudayaan berbagai kemampuan, nilai, dan sikap seorang Indonesia modern yang demokratis dan bertanggung jawab. ${ }^{18}$

Selain itu, hasil didikan itu sangat dipengaruhi oleh integritas kemanusia-an pendidiknya, yaitu : ${ }^{19}$

a. Berjiwa besar ataukah bermentalitas kerdil;

b. Jujur ataukah koruptif;

c. Bersahaja atau serba semu, apalagi bermewah-mewah;

d. Konsekuen ataukah angin-anginan, mengikuti liak-liuk irama gendang seruling yang membiuskan menghanyutkan.

Di sini, pendidik atau dosen atau guru juga mempengaruhi pembentukan karakter dari anak didik. Apa yang

\footnotetext{
${ }^{18}$ Ibid., hlm. 21- 22.

19 Abdul Ghofur Anshori dan Shobirin Malian (Ed.), Op.Cit., hlm. 61.
}

dilakukan oleh pendidik, tentunya akan ditiru oleh anak didiknya, sehingga kualitas pendidik juga menentukan kualitas sumber daya manusia yang dihasilkan.

Apabila karakteristik kebijakan pendidikan tinggi di Indonesia berlandaskan nilai-nilai Pancasila dan Undang-Undang Dasar Negara Republik Indonesia Tahun 1945, akan dengan mudah membangun sumber daya manusia yang berkualitas dan berdaya saing global.

Hal yang terpenting adalah manfaat dari keberadaan pendidikan tinggi bagi masyarakat. Sangat disayangkan apabila pendidikan tinggi mampu men-cetak para pekerja yang profesional dan berkualitas tinggi, akan tetapi di dalam masyarakat, keberadaannya tidak diakui dan tidak memberikan kontribusi bagi masyarakat. Di sinilah tugas pemerintah dan seluruh rakyat Indonesia untuk bekerjasama dalam meningkatkan pendidikan nasional, agar sumber daya manusia Indonesia diakui di mata internasional.

Reformasi kurikulum pendidikan tinggi berbasis mutualisme antara hukum nasional dan hukum internasional sangat diperlukan, karena persaingan di dunia global, yang berakibat juga terhadap persaingan perguruan tinggi di dalam negeri maupun di luar negeri, sehingga perguruan tinggi dituntut untuk 
menghasilkan lulusan yang dapat bersaing dalam dunia global.

Bergesernya orientasi pendidikan tinggi yang tidak lagi hanya meng-hasilkan manusia cerdas berilmu, tetapi juga yang mampu menerapkan ke-ilmuannya dalam kehidupan di masyarakatnya (kompeten dan relevan), yang lebih berbudaya, harus dipupuk secara sumber daya kemanusiaan (pengajar), dan berbasis kompetensi internasional.

Selain mengembangkan kemampuan intelektual dan skill bagi para peserta didik, kurikulum pendidikan tinggi di Indonesia harus diarahkan pula pada pengembangan akhlak mulia, yang bersumber pada ajaran agama sebagai basis filosofisnya, sebagaimana yang terdapat di dalam sila Pancasila terutama Sila Ketuhanan Yang Maha Esa, yang mana pendidikan nasional, antara lain bertujuan untuk membentuk manusia yang bertaqwa kepada Tuhan yang Maha Esa dan Sila Kemanusiaan Yang Adil dan Beradab.

Tidak ada salahnya jika bangsa Indonesia belajar dari proses reformasi pendidikan tinggi di negara Spanyol. Reformasi pendidikan di negara Spanyol tidak hanya berhenti di tahun 2001 yang ditandai dengan Ley de Reforma Universitaria (LRU), namun terus bergulir dengan ditetapkannya Undang-Undang Pendidikan (Ley Organica de Educacion, LOE) sebagai proses refor-masi umum pendidikan pada tahun 2006. Undangundang pendidikan yang baru ini berbasis pada 3 (tiga) prinsip atau tujuan umum, yakni : ${ }^{20}$

a. Kualitas dan kesetaraan dalam pendidikan;

b. Kerjasama seluruh sektor dalam komunitas pendidikan dalam upaya men-capai proses pembelajaran;

c. Bentuk komitmen penuh pada tujuan bersama negara-negara Uni Eropa dalam mencapai proses konvergensi sistem pendidikan dan pelatihan.

Waktu yang ditetapkan untuk mengimplementasikan semua tujuan tersebut adalah 5 (lima) tahun yang pelaksanaannya dilakukan secara bertahap. Ley Organica de Educacion juga dimaksudkan pula untuk mempersiapkan perguruan tinggi Spanyol mengikuti persetujuan Bologna (1999) yang ditandatangani oleh 30 negara Eropa, yakni Austria, Belgia, Bulgaria, Republik Ceko, Denmark, Estonia, Finlandia, Perancis, Jerman, Yunani, Hungaria, Islandia, Irlandia, Italia, Letonia, Lithuania,

20 Ari Warokka, (2008), 20 Tahun Reformasi Pendidikan Tinggi Spanyol : Apa yang Dapat Dipelajari Oleh Indonesia, PPI Spanyol: Madrid, hlm. 16. 
Luxemburg, Malta, Belanda, Norwegia, Rolandia, Portugal, Rumania, Slowakia, Slovenia, Spanyol, Swedia, Swiss, dan Inggris. Proses Bologna ini telah diratifikasi di Paris, Lisabon, Salamanca, Berlin, Barcelona dan Bergen. Proses Bologna ini berupaya untuk : ${ }^{21}$

a. Melakukan harmonisasi sistem pendidikan tinggi di Eropa;

b. Transfer pengetahuan berbasis pembelajaran daripada pengajaran (based on learning more than on teaching);

c. Meningkatkan kapasitas perguruan tinggi menarik orang muda untuk studi dan meningkatkan kompetensi;

d. Meningkatkan kualitas dan keunggulan sebagai faktor kunci kesuksesan;

Membantu mobilitas, saling mengakui gelar kesarjanaan dan pendidikan berkelanjutan

\section{Penutup}

Kurikulum merupakan pencerminan dari semua cita-cita dan pikiran dalam pendidikan, Pendidikan tinggi merupakan bagian dari sistem pendidikan nasional memiliki peran strategis dalam mencerdaskan kehidupan bangsa dan memajukan ilmu pengetahuan dan teknologi. Pembaharuan sistem kebijakan

21 Ibid. pendidikan tinggi sangatlah penting dilakukan, mengingat bangsa Indonesia menghadapi beragam tantangan, Kurikulum pendidikan tinggi saat ini berbasis kompetensi yang mengacu pada kualifikasi akademik. Alasan dilakukannya pembaharuan sistem kebijakan pendidikan tinggi adalah karena kualitas lulusan pendidikan tinggi yang belum mampu menjawab kebutuhan dan daya saing global.

Adanya ketimpangan antara profil lulusan pendidikan tinggi dengan standar kualifikasi tenaga kerja yang dibutuhkan pasar kerja, adanya tuntutan perubahan kurikulum dengan Kerangka Kualifikasi Nasional Indonesia (KKNI) dan Standar Nasional Pendidikan Tinggi (SNPT) yang mempunyai daya saing global.

\section{E. Daftar Pustaka}

Buku

Abdul Ghofur Anshori dan Shobirin Malian (Ed.), (2008), Membangun Hukum Indonesia, Kumpulan Pidato Guru Besar Ilmu Hukum dan Filsafat, Cetakan Pertama, Kreasi Total Media, Yogyakarta,

Ari Warokka, (2008), 20 Tahun Reformasi Pendidikan Tinggi Spanyol : Apa yang Dapat Dipelajari Oleh Indonesia, PPI Spanyol, 
Ateng Syafrudin, (2008), Catatan Kecil Tentang Pemerintahan, Pendidikan dan Hukum, dalam Sri Rahayu Oktoberina dan Niken Savitri (Ed.), Butir-butir Pemikiran Dalam Hukum, Memperingati 70 Tahun Prof. Dr. B. Arief Sidharta, S.H., Cetakan Pertama, Refika Aditama, Bandung,

Esmi Warassih, (2011), Pranata Hukum Sebuah Telaah Sosiologis, Cetakan Kedua, Badan Penerbit Universitas Diponegoro, Semarang.

Forum Mangunwijaya, (2007), Kurikulum yang Mencerdaskan, Visi 2030 dan Pendidikan Alternatif, Cetakan Pertama, Kompas Media Nusantara. Jakarta.

Peter Mahmud Marzuki, (2005), Penelitian hukum, Kencana Prenada Group: Jakarta
Jurnal

Suyadi , (2012), Integrasi Pendidikan Islam Dan Neurosains Dan Implikasinya Bagi Pendidikan Dasar (Pgmi), Al-Bidāyah, Vol 4 No. 1, Juni.

Internet

Fitri, (2017), Kurikulum Nasional Berbasis Kompetensi Mengacu Pada KKNI, http://www.kopertis12.or.id/2013/04 /28/kurikulum-nasional-berbasiskompetensi-mengacu-padakkni.html ,[Akses 9 Agustus 2017].

USAID, (2017), Reformasi Pendidikan Tinggi di Indonesia, http://www.prestasiiief.org/index.php/id/feature/108reformasi-pendidikan-tinggi-diindonesia, [Akses 9 Agustus 2017]. 